\title{
Multiple timescale processes drive ecosystem metabolism in eelgrass (Zostera marina) meadows
}

\author{
Jennie E. Rheuban ${ }^{1,2, *}$, Peter Berg ${ }^{1}$, Karen J. McGlathery ${ }^{1}$ \\ ${ }^{1}$ Department of Environmental Sciences, University of Virginia, Charlottesville, Virginia 22904-4123, USA \\ ${ }^{2}$ Present address: Marine Chemistry and Geochemistry Department, Woods Hole Oceanographic Institution, Woods Hole, \\ Massachusetts 02543-1541, USA
}

\begin{abstract}
The oxygen flux between benthic ecosystems and the overlying water column is a measure of metabolic status and a commonly used proxy for carbon cycling. In this study, oxygen flux was measured seasonally using the eddy correlation technique in a restored eelgrass (Zostera marina L.) meadow in the Virginia coastal bays (USA). In 5 intensive field campaigns, we covered seasonal variation in oxygen metabolism and biomass with overlap in late summer to observe interannual variability. The high-resolution measurements allowed identification of the drivers of metabolism at multiple timescales: minute to hourly, daily, and monthly to seasonally. There was a strong correlation between nighttime hourly fluxes and current velocity that varied seasonally with seagrass shoot density and temperature. No similar relationship was observed during the day. A hysteresis effect in oxygen flux throughout the day was observed during October and August that was most likely due to increased respiration $(\mathrm{R})$ in the afternoon. In October, net community production was $90 \%$ lower in the afternoon than in the morning at the same irradiance. From this hysteresis, we calculated that daytime $\mathrm{R}$ may be up to 2.5 -fold larger than nighttime $\mathrm{R}$. The magnitudes of daily gross primary production (GPP) and $\mathrm{R}$ were well correlated throughout the year with close to a 1:1 ratio that reflected a tight coupling between GPP and R on daily to seasonal timescales. Our results document the dynamic nature of oxygen fluxes that, when integrated over time, translate into highly variable rates of ecosystem metabolism over daily to seasonal timescales. This variation must be incorporated to accurately determine trophic status.
\end{abstract}

KEY WORDS: Zostera marina L. · Net ecosystem metabolism $\cdot$ Oxygen $\cdot$ Production $\cdot$ Respiration written consent of the publisher

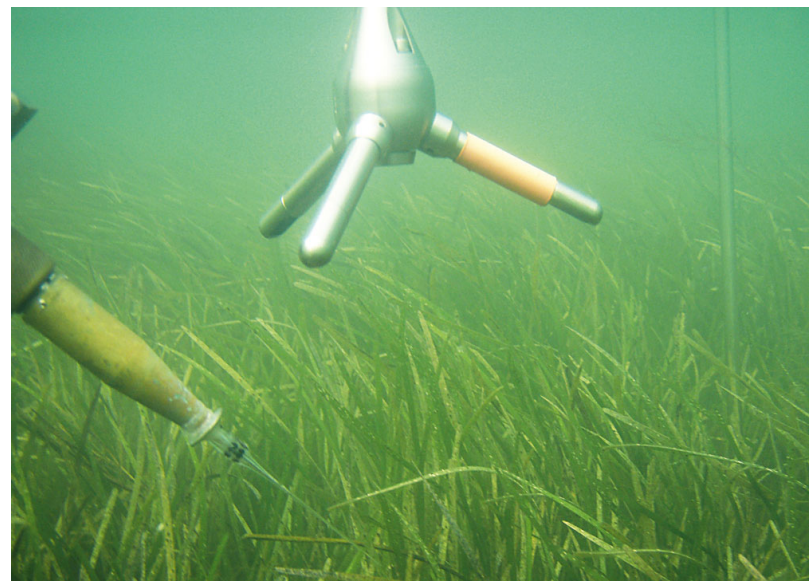

Measurements of seagrass ecosystem metabolism using the eddy correlation technique show high variability related to processes that act on multiple timescales.

Photo: Andrew Hume

\section{INTRODUCTION}

Seagrass meadows are significant contributors to marine carbon sequestration due to high rates of both net primary production (Duarte et al. 2010) and carbon burial (Duarte et al. 2011, Mcleod et al. 2011, Fourqurean et al. 2012). The baffling effect of the seagrass canopy enhances sedimentation of particles from the water column and reduces sediment resuspension (Fonseca \& Fisher 1986, Gacia et al. 2002, Hansen \& Reidenbach 2012), and much of the carbon buried in seagrass sediments is of allochthonous origin (Kennedy et al. 2010). High rates of primary production (Barrón et al. 2004, Eyre et al. 2011, Hume et 
al. 2011) are supported by high nutrient uptake rates, and seagrass meadows act as a coastal filter that improves local water quality (McGlathery et al. 2007). Given that seagrass meadows can have very high rates of carbon burial (Mcleod et al. 2011, Greiner et al. 2013) and store up to $19.9 \mathrm{Pg}$ of carbon globally (Fourqurean et al. 2012), a detailed understanding of their metabolism is important as a key component of carbon cycling in coastal systems.

Zostera marina L. has a broad geographical range (Short et al. 2007), and individual sites show strong acclimation to seasonal variations in light and temperature (Moore et al. 1997, Staehr \& Borum 2011). Seagrasses increase photosynthetic efficiency and pigment concentration in response to lower light levels (Masini \& Manning 1997) and decrease respiratory requirements with lower temperatures (Moore et al. 1997). In the Mid-Atlantic, Z. marina is sensitive to high temperatures in mid-summer due to higher light requirements associated with increased respiration (Moore et al. 1997, 2012). As a result, seagrass production may be limited by temperature stress at shallow depths and light stress at deeper depths (Carr et al. 2010, McGlathery et al. 2012, Reynolds et al. 2012).

Compared to unvegetated sites, seagrass meadows have higher rates of both production and respiration (Barrón et al. 2004, Eyre et al. 2011, Hume et al. 2011). However, on a net basis, ecosystem metabolism in $Z$. marina meadows is widely variable, with both net autotrophy and heterotrophy reported for different locations (Duarte et al. 2010; see Table 2). Because of the large variability in reported net metabolism, a deeper understanding of the factors that influence seagrass community metabolism is warranted.

Here, we assessed $\mathrm{O}_{2}$ fluxes in seagrass communities using the eddy correlation technique (Berg et al. 2003). The technique has been used in traditionally difficult environments for measuring benthic $\mathrm{O}_{2}$ fluxes such as rocky hard substrates, seagrass meadows, and permeable sediments (Glud et al. 2010, Hume et al. 2011, Berg et al. 2013). The approach has several advantages over traditional flux-chamber methods as it is non-invasive (Berg et al. 2003), has a higher temporal resolution (Hume et al. 2011, Berg et al. 2013), and integrates ecosystem-scale fluxes over a large sediment surface area (Berg et al. 2007) and in heterogeneous environments (Rheuban \& Berg 2013). Another common technique is the open-water method (Odum 1956), which derives ecosystem metabolism from diurnal changes in the $\mathrm{O}_{2}$ concentration (e.g. Caffrey 2004). This method has some advan- tages over the eddy correlation technique, most notably that it allows long continuous time series to be collected and translated into daily metabolic rates. However, these rates are dependent on knowing the air-sea exchange, which is a parameter that is difficult to assess in some environments (Raymond \& Cole 2001).

Metabolism can be determined by measuring dissolved inorganic carbon (DIC) or $\mathrm{O}_{2}$ fluxes. Oxygenbased methods are typically more commonly used because instrument deployment and data analysis are relatively straightforward (Glud 2008). However, $\mathrm{O}_{2}$ fluxes may underestimate ecosystem respiration when anaerobic metabolism is prevalent and some reduced metabolites escape the sediment before being re-oxidized (Canfield et al. 1993, Heip et al. 1995, Glud 2008). In turn, DIC-based measurements may be substantially influenced by changes in alkalinity, calcification, and carbonate precipitation or dissolution (Barrón et al. 2006). Although each method has a different set of uncertainties, when integrated annually, the DIC: $\mathrm{O}_{2}$ flux ratio has been estimated to range from 0.8 to 1.2 (Glud 2008 and references therein).

The purpose of this study was to investigate processes occurring at multiple timescales that influence ecosystem-scale metabolism of seagrass meadows. We show that multiple drivers impact $\mathrm{O}_{2}$ fluxes in seagrass meadows, as a measure of ecosystem metabolism, including that (1) light and flow control minute to hourly $\mathrm{O}_{2}$ fluxes; (2) feedbacks between production and respiration influence daily metabolism; and (3) seasonal ecosystem metabolism is dependent on temperature and shoot density.

\section{MATERIALS AND METHODS}

\section{Study site}

The study site, South Bay $\left(37^{\circ} 15^{\prime} 43.662^{\prime \prime}\right.$ N, $75^{\circ} 48^{\prime}$ $\left.54.554^{\prime \prime} \mathrm{W}\right)$, is located in the shallow subtidal lagoons of the Virginia Coast Reserve (VCR Long-Term Ecological Research site) between the Delmarva Peninsula and the barrier island chain (USA). South Bay is the location of a large-scale Zostera marina restoration via seeding carried out in the early 2000s, and has resulted in over 1700 ha of dense seagrass meadows as of 2011 (Orth et al. 2006, 2010, 2012, McGlathery et al. 2012). The site is approximately $1.3 \mathrm{~m}$ deep at mean sea level with a $1 \mathrm{~m}$ tidal range, and is relatively protected from waves by the barrier islands. 


\section{Data collection}

Data were collected during 4 major seasonal periods for $Z$. marina metabolism based on temperature (Orth \& Moore 1986): fall regrowth after summer heat stress, low winter growth, early summer peak growth, and late-summer heat stress. Data were collected in August 2011, October 2011, February 2012, June 2012, and August 2012.

Benthic $\mathrm{O}_{2}$ fluxes were measured with 1 or 2 eddy correlation systems (Berg et al. 2003) that each consisted of an acoustic Doppler velocimeter (ADV, Nortek-AS) coupled to a fast responding $(90 \%$ response $<0.3$ s) Clark-type $\mathrm{O}_{2}$ microsensor (Unisense), and a submersible pico-amplifier (GEOMAR, see McGinnis et al. 2011). These sensors were mounted on a stainless steel tripod designed to limit disturbances of natural flow (Berg \& Huettel 2008) and recorded data at 32 or $64 \mathrm{~Hz}$. Data were recorded continuously for 14.5 min periods with a $0.5 \mathrm{~min}$ pause between. These fluxes are referred to as 15 min fluxes below. The eddy correlation system was adjusted so the measuring volume was $\sim 31 \mathrm{~cm}$ above the bottom and thus above the canopy, ensuring that measurements incorporated $\mathrm{O}_{2}$ metabolism from all components of the seagrass meadow. Care was taken to ensure that the instrument was leveled and the $x$-axis was oriented along the dominant mean current direction. To avoid breaking the microsensor tip when the seagrass blades extend vertically at low current flow (Hume et al. 2011), blades were clipped in a $0.25 \mathrm{~m}^{2}$ area directly under the microsensor. The sediment surface area that contributes to the flux, termed the footprint, is an elongated elliptical shape that can be on the order of 10 to $100 \mathrm{~m}$ long and 2 to $7 \mathrm{~m}$ wide, and is dependent on the measuring height and the sediment surface roughness (Berg et al. 2007). Understanding the size and shape of the footprint is important for putting the fluxes into biological context, for example in heterogeneous environments (Rheuban \& Berg 2013); however, a clear definition of the footprint area is not needed to complete the flux calculations. Deployments $(24 \mathrm{~h})$ were performed in succession for up to $1 \mathrm{wk}$ during each season, with 1 to $2 \mathrm{~h}$ gaps between deployments to download data and replace batteries and $\mathrm{O}_{2}$ microsensors as needed. Because the microsensors are fragile and often break mid-deployment, this resulted in fewer $24 \mathrm{~h}$ periods of data recorded than deployments made.

Environmental parameters that affect $\mathrm{O}_{2}$ fluxes were also measured during deployments. Photosyntheti- cally active radiation (PAR) reaching the canopy was recorded every $15 \mathrm{~min}$ using a submersible planar $2 \pi$ Odyssey PAR sensor (Dataflow Systems). This sensor was calibrated to a LI-193SA (LI-COR Biosciences) scalar $4 \pi$ PAR sensor as described by Long et al. (2012). Mean $\mathrm{O}_{2}$ concentration was measured using either an LDO optode (Hach Systems) in a waterproof housing or a submersible $\mathrm{O}_{2}$ optode (miniDOT, PME) mounted at the measuring height of the eddy correlation system. Both sensors recorded $\mathrm{O}_{2}$ concentration and temperature every $15 \mathrm{~min}$. Mean current velocity, water depth, and current direction were derived from the ADV data. Seagrass shoot density was measured at the end of each deployment period in August 2011 and 2012, October 2011, and June 2012 by counting all shoots located within replicate ( $\mathrm{n}=4-10) 0.25 \mathrm{~m}^{2}$ quadrats haphazardly thrown within the footprint of the eddy correlation system. Due to low water temperatures in February 2012, shoot density was counted within 8 haphazardly thrown $0.125 \mathrm{~m}^{2}$ quadrats.

\section{Data analysis}

Benthic $\mathrm{O}_{2}$ fluxes were extracted using EddyFlux2.0 software (P. Berg unpubl.) from data averaged to $16 \mathrm{~Hz}$ from raw 64 or $32 \mathrm{~Hz}$ eddy correlation data. The $\mathrm{O}_{2}$ flux was calculated as:

$$
J_{E C}=\overline{C^{\prime} u_{z}^{\prime}}
$$

where $C^{\prime}$ and $u_{z}^{\prime}$ are the fluctuating components of the $\mathrm{O}_{2}$ concentration and vertical velocity, respectively. These variables were separated from the means using Reynolds decomposition, where $C^{\prime}=$ $C-\bar{C}$ and $u_{z}^{\prime}=u_{z}-\overline{u_{z}}$ where $C$ and $u_{z}$ are the measured data averaged to $16 \mathrm{~Hz}$, and overbars represent time averaging (Berg et al. 2003). For all flux extractions in this study, $\bar{C}$ and $\overline{u_{z}}$ were defined as leastsquare linear fits to $C$ and $u_{z}$ in each $14.5 \mathrm{~min}$ time interval, usually referred to as linear detrending (Lee et al. 2004). Through careful data quality control, sections of $\mathrm{O}_{2}$ data were removed where the microsensors were impacted by floating debris or were fouled (Berg et al. 2013). Rotation of the velocity field prior to flux extractions has been deemed important if the instrument is tilted relative to the sediment surface (Reimers et al. 2012, Lorke et al. 2013). However, caution must be taken when rotating the velocity data if significant surface waves are present (Reimers et al. 2012) or when the mean current velocity is very small. Here, fluxes were extracted from both rotated and unrotated velocity fields, and differences in the 
underlying distributions were tested using a 2-sample Kolmogorov-Smirnov (K-S) test (Massey 1951) to determine whether there were significant differences between the 2 extraction procedures. A significant difference was only found for 1 deployment during August 2012 ( $p>0.05$ for all other deployments, $n=20$ ) and consisted of only $4 \mathrm{~h}$ of data dominated by wave motions. Thus, fluxes based on unrotated velocity data for all deployments were used. Additionally, fluxes may be temporarily biased due to transient velocity conditions in accelerating or decelerating flows (Holtappels et al. 2013). However, our measurements were obtained over 6 to 12 full tidal cycles per sampling period and would contain biases with opposite signs which thus would cancel out (Holtappels et al. 2013).

Usually the extracted eddy flux is taken as a direct representation of the benthic flux sought (Berg et al. 2003, Lorrai et al. 2010). However, several additional assumptions must be fulfilled for this analogy to hold (Hume et al. 2011, Berg et al. 2013, Holtappels et al. 2013). The assumption that the storage of $\mathrm{O}_{2}$ in the water column between the sediment surface and the measuring point is negligible should be carefully evaluated in some applications, such as over shallowwater seagrass beds. In order to obtain measurements from above the seagrass canopy, a relatively large measuring height must be used. This large measuring height, combined with the large expected diurnal fluctuation in mean water column $\mathrm{O}_{2}$ concentration may result in significant changes in stored $\mathrm{O}_{2}$ in the water column. As documented below, this concentration change can amount to $175 \mu \mathrm{mol} \mathrm{l}^{-1}$ though a $5 \mathrm{~h}$ period during the peak summer season, which at a measuring height of $\sim 31 \mathrm{~cm}$ translates to an aerial change in storage of approximately $260 \mathrm{mmol} \mathrm{O}_{2}$ $\mathrm{m}^{-2} \mathrm{~d}^{-1}$ in the water column below the measuring point. Because this rate is driven by benthic production-respiration processes in the seagrass meadow, it represents an interim distortion of the benthic flux if this flux is assumed to equal the measured eddy flux. However, a correction for this storage in the water column below the measuring point can be applied as:

$$
J_{\text {benthic }}=J_{E C}+\int_{0}^{h} \frac{\mathrm{d} C}{\mathrm{~d} t} \mathrm{~d} z
$$

where $J_{\text {benthic }}$ is the benthic flux, $J_{E C}$ is the measured eddy flux, $h$ is the measuring height, and $\frac{\mathrm{d} C}{\mathrm{~d} t}$ is the temporal change in mean $\mathrm{O}_{2}$ concentration in the water column. The latter can be extracted from the eddy correlation data when the fluctuation and mean concentration components are isolated, done here by linear detrending.
After initial flux extractions, data were processed as in Hume et al. (2011), where 15 min fluxes were averaged to produce hourly fluxes and associated standard errors. These averages were then grouped into light data (PAR > $1.0 \mu \mathrm{mol}$ photons $\mathrm{m}^{-2} \mathrm{~s}^{-1}$ ) and dark data $\left(\mathrm{PAR}<1.0 \mu \mathrm{mol}\right.$ photons $\mathrm{m}^{-2} \mathrm{~s}^{-1}$ ) for use in regression analyses. Daily values of ecosystem respiration (R), gross primary production (GPP), and net ecosystem metabolism (NEM) were determined for each of the continuous $24 \mathrm{~h}$ deployments as in Hume et al. (2011):

$$
\begin{aligned}
\mathrm{R} & =\left(\sum \text { Flux }_{\text {dark }}+\frac{\sum \text { Flux }_{\text {dark }}}{h_{\text {dark }}} h_{\text {light }}\right) \\
\mathrm{GPP} & =\left(\sum \text { Flux }_{\text {light }}+\frac{\mid \sum \text { Flux }_{\text {dark }} \mid}{h_{\text {dark }}} h_{\text {light }}\right) \\
\mathrm{NEM} & =\left(\sum \text { Flux }_{\text {dark }}+\sum \text { Flux }_{\text {light }}\right)
\end{aligned}
$$

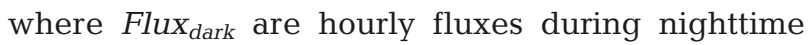
$\left(\mathrm{mmol} \mathrm{O}_{2} \mathrm{~m}^{-2} \mathrm{~h}^{-1}\right)$, Flux $x_{\text {light }}$ are the equivalent daytime values, $h_{\text {dark }}$ are the number of hours of darkness, and $h_{\text {light }}$ are the number of hours of light. In the few cases where hourly values were missing, for example due to sensor fouling or breakage, values were interpolated using regressions with data from the same deployment. During August 2012, there were significant difficulties during all deployments with breakage or fouling of $\mathrm{O}_{2}$ microsensors, and no continuous $24 \mathrm{~h}$ deployments were available to calculate R, GPP, and NEM. For this one season, all 15 min fluxes were binned by hour of the day to generate one continuous $24 \mathrm{~h}$ record to estimate seasonal R, GPP, and NEM from Eqs. (3), (4), \& (5). This alternative approach was tested using data from August 2011 where 5 full $24 \mathrm{~h}$ records were obtained and resulted in the same metabolic rates within $4 \%$.

\section{RESULTS}

\section{Site characteristics and eddy correlation data}

Environmental conditions measured, such as temperature, daily irradiance, and mean flow conditions, are given in Table 1.

Fluxes were often more strongly coupled with available light after accounting for $\mathrm{O}_{2}$ stored between the measuring point and the bottom (Eq. 2, Fig. 1). Published aquatic eddy correlation studies have until now deemed this correction unnecessary (Berg et al. 2003, Glud et al. 2010, Hume et al. 2011). The rationale has been that data were recorded close 

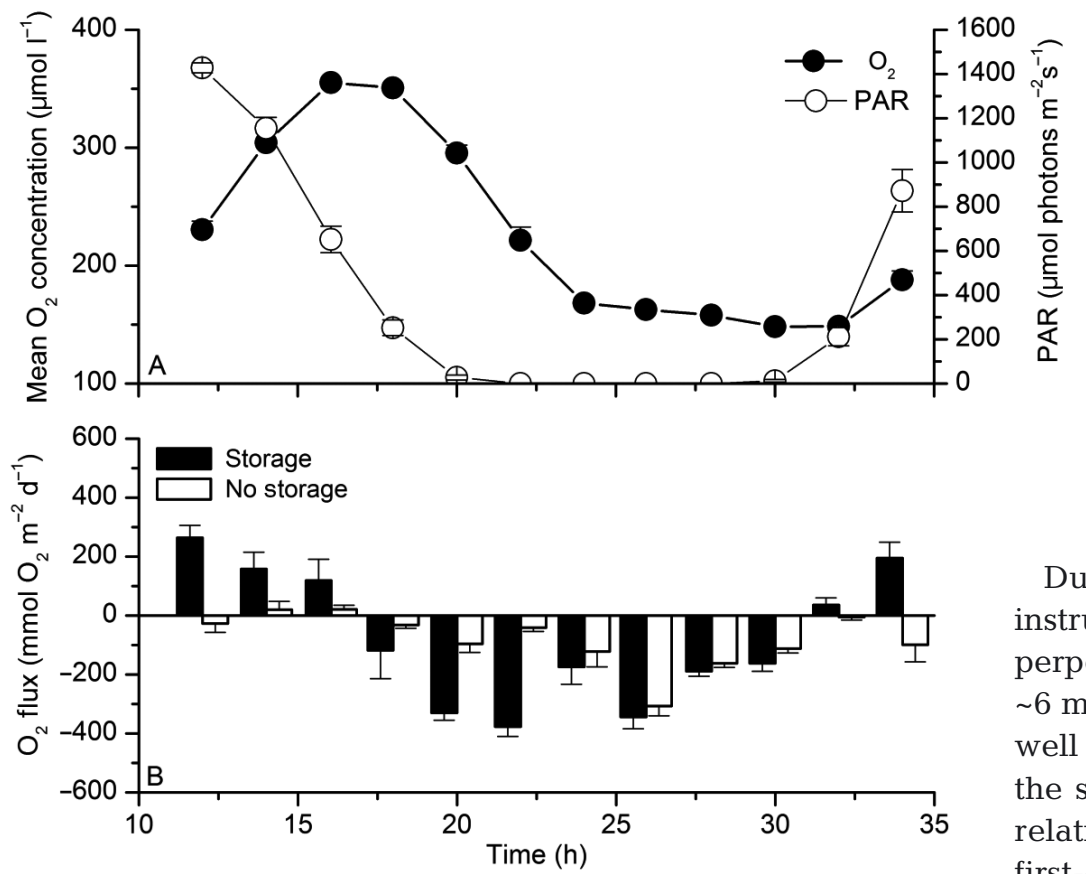

Fig. 1. Example from August 2011 of flux calculations with and without storage correction. (A) Photosynthetically active radiation (PAR) reaching the canopy and mean water column $\mathrm{O}_{2}$ concentration. (B) Comparison of flux extraction accounting for storage vs. no storage. Positive fluxes represent a release. Error bars are standard error

to the sediment surface, only minor changes in mean water column $\mathrm{O}_{2}$ concentration were recorded, or both. During some sampling periods, the mean $\mathrm{O}_{2}$ concentration varied by more than $150 \%$. Such large changes in mean $\mathrm{O}_{2}$ concentration, combined with a measuring height of $\sim 31 \mathrm{~cm}$, makes the storage term correction substantial, as illustrated in Fig. 1. Although some uncertainty is associated with the formulation of the storage term (Eq. 2), for example at intermittent low-flow conditions, where recorded mean $\mathrm{O}_{2}$ concentrations at the measuring point may not represent the entire body of water below, we determined that the best flux estimates at this site were obtained with the storage correction (Fig. 1). As a result, all fluxes and metabolic rates reported be-

Table 1. Mean and standard deviation $( \pm \mathrm{SD})$ of environmental conditions during sampling periods

\begin{tabular}{|lrcr|}
\hline Sampling date & $\begin{array}{c}\text { Temp } \\
\left({ }^{\circ} \mathrm{C}\right)\end{array}$ & $\begin{array}{c}\text { Light } \\
\left(\mu \mathrm{mol} \text { photons } \mathrm{m}^{-2} \mathrm{~s}^{-1}\right)\end{array}$ & $\begin{array}{c}\text { Velocity } \\
\left(\mathrm{cm} \mathrm{s}^{-1}\right)\end{array}$ \\
\hline August 2011 & $30.1 \pm 1.6$ & $547.1 \pm 508.2$ & $3.2 \pm 2.4$ \\
October 2011 & $17.0 \pm 2.9$ & $214.7 \pm 189.5$ & $4.5 \pm 2.7$ \\
February 2012 & $9.4 \pm 1.1$ & $186.1 \pm 160.7$ & $3.9 \pm 2.8$ \\
June 2012 & $27.6 \pm 1.3$ & $350.2 \pm 345.3$ & $1.6 \pm 1.1$ \\
August 2012 & $27.4 \pm 1.1$ & $334.5 \pm 235.6$ & $3.5 \pm 2.0$ \\
\hline
\end{tabular}

low were extracted with the storage correction applied. It should be noted that calculations of NEM for the seagrass meadows are usually only affected minimally by this storage correction because the net change in mean water column $\mathrm{O}_{2}$ concentration for a full $24 \mathrm{~h}$ period was typically small. As an example, for the data shown in Fig. 1, NEM values calculated with and without the storage correction differed by less than $3 \%(-64.9$ vs. $-66.9 \mathrm{mmol} \mathrm{O}_{2} \mathrm{~m}^{-2} \mathrm{~d}^{-1}$ ).

During June 2012, 2 eddy correlation instruments were deployed simultaneously perpendicular to the main current direction $\sim 6 \mathrm{~m}$ apart. This was done to determine how well the data from one instrument represents the seagrass meadow as a whole. Using the relationships in Berg et al. (2007) to obtain a first-order estimate, we determined that the footprints were approximately $2 \mathrm{~m}$ wide, and by deploying the instruments perpendicular to the main current direction, we ensured the footprints did not overlap. Flux data from the 2 concurrent $24 \mathrm{~h}$ deployments showed a clear expected diurnal cycle related to light and an excellent agreement between the 2 instruments (Fig. 2). This indicates that our measured fluxes and metabolic rates are representative of the seagrass meadow as a whole.

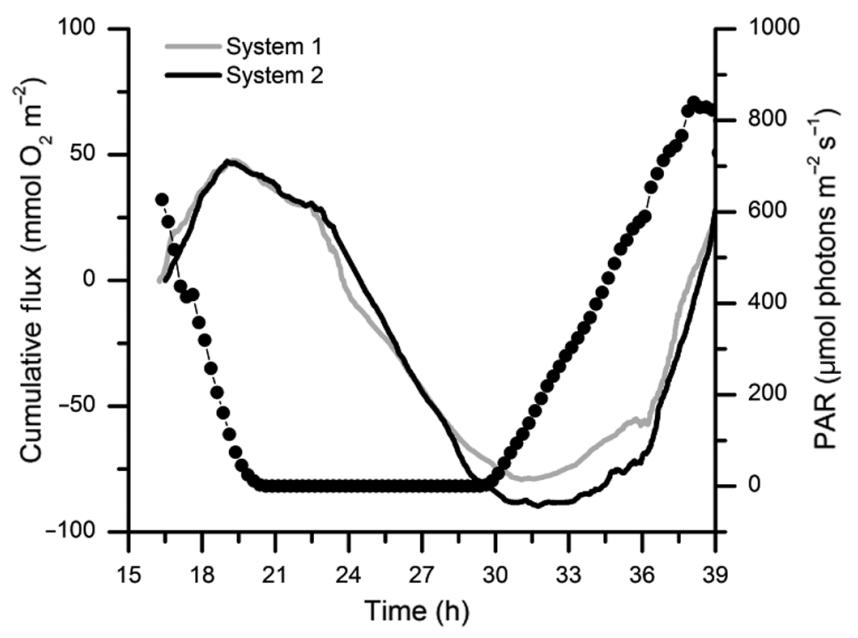

Fig. 2. Two eddy correlation instruments deployed in June 2012 side by side for $24 \mathrm{~h}, \sim 6 \mathrm{~m}$ apart with no overlapping footprints. Figure shows cumulative fluxes from both instruments over the $24 \mathrm{~h}$ period (lines) and photosynthetically active radiation ( $\mathrm{PAR}_{i}$ dots). There is good agreement between the cumulative fluxes of both instruments throughout the deployment 
A typical example of data collected in June 2012 is given in Fig. 3. The 15 min fluxes are shown with associated environmental variables. The calculated fluxes were well correlated with light, as illustrated by a strong storm event that began around Hour 38 with large reduction in available light and resulted in a decline in measured $\mathrm{O}_{2}$ fluxes. Data are missing between 23.0-24.5 and 30.0-30.25 h due to fouling of the $\mathrm{O}_{2}$ microsensor.

\section{Ecosystem metabolism in eelgrass meadows}

Averages of $\mathrm{O}_{2}$ fluxes binned by hour of day (Fig. 4) were highly variable throughout the year and showed an expected diurnal cycle driven mainly by light for each season. Both daytime and nighttime fluxes varied between seasons, as well as within individual seasons. These high temporal-resolution data show that variation in fluxes throughout the day was as high as variation between seasons (Fig. 4).

Nighttime $\mathrm{O}_{2}$ flux (respiration) was negatively correlated with flow during all seasons except February (Fig. 5). Data were binned by mean flow velocity to illustrate this relationship, and linear regression analysis was used on both binned and unbinned data to show its significance (October: $p=0.035$ for unbinned data, $\mathrm{p}=0.012, \mathrm{r}^{2}=0.83$ for binned data; June: $p=0.027$ for unbinned data, $p=0.0069, r^{2}=$ 0.94 for binned data; August: $p=0.0075$ for unbinned data, $\mathrm{p}=0.0046, \mathrm{r}^{2}=0.95$ binned data). The slope of the regressions, representing the strength of flow stimulation of respiration, changed seasonally, with the strongest effect observed during June.

A clear hysteresis effect was observed during October and August when all fluxes from each sampling season were averaged by hour of day and plotted as a function of light (Fig. 6, shown for October). Morn-

June 21-23, 2012
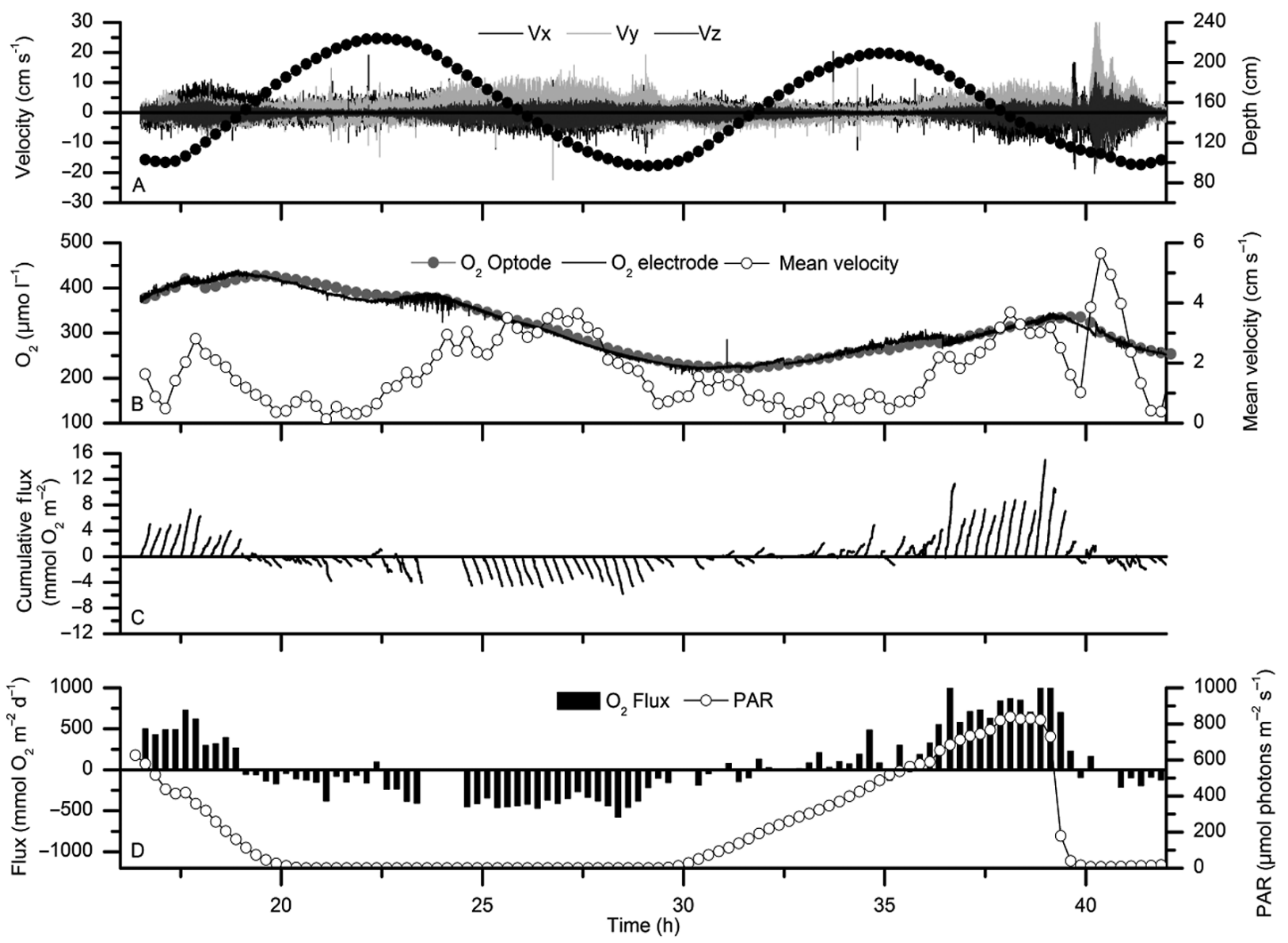

Fig. 3. Example eddy correlation deployment from June 2012 over $\sim 32 \mathrm{~h}$. (A) Velocity (V) in $x, y$, and $z$ directions (lines) and water depth (dots). (B) $\mathrm{O}_{2}$ concentration from the microsensor and a stable optode and mean current velocity. (C) Cumulative fluxes over 15 min periods. (D) 15 min $\mathrm{O}_{2}$ fluxes and photosynthetically active radiation (PAR) reaching the canopy. Positive 

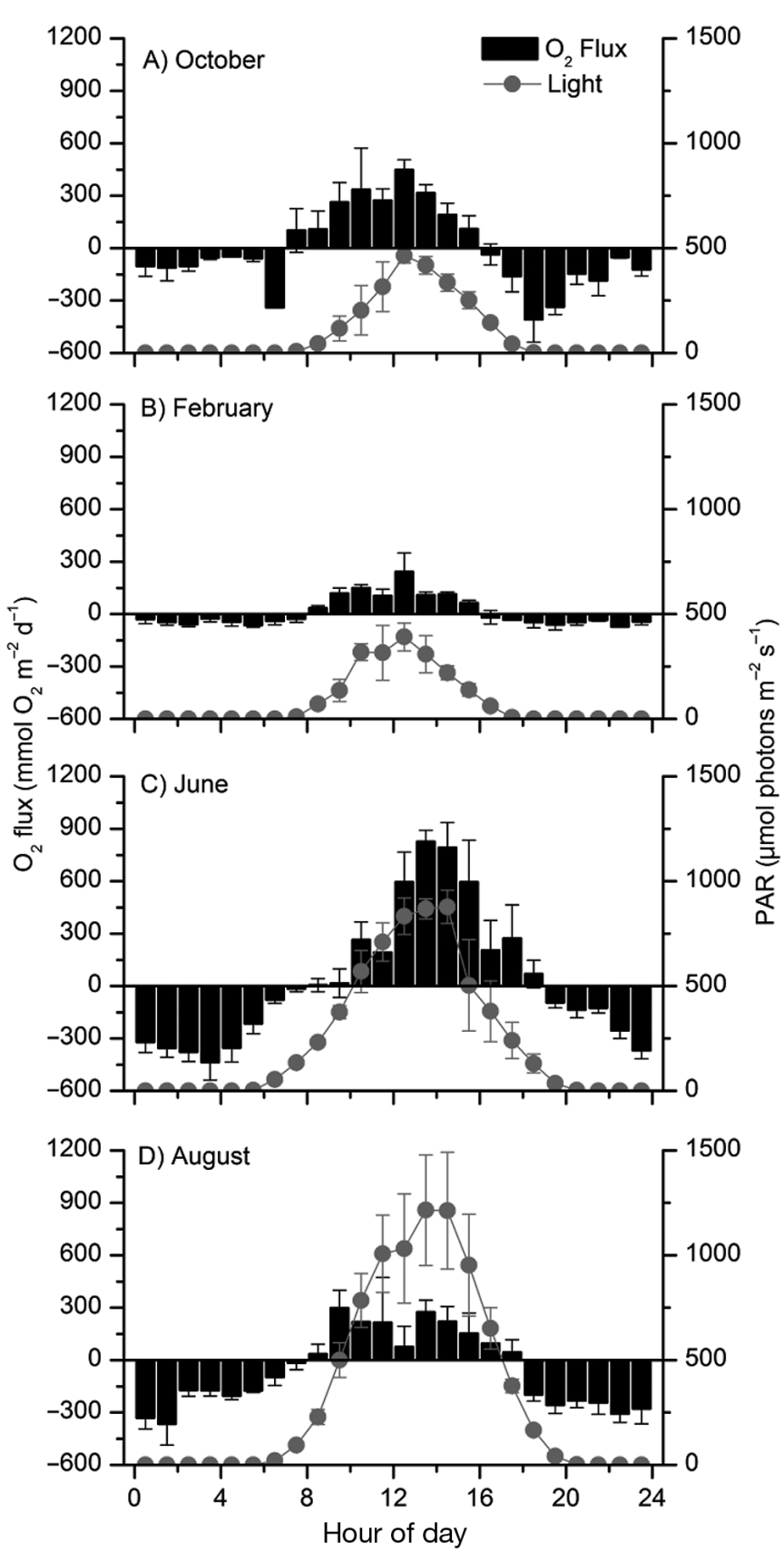

Fig. 4. Binned hourly average $\mathrm{O}_{2}$ fluxes and available photosynthetically active radiation for (A) October, (B) February,

(C) June, and (D) August. Error bars are standard error

ing $\mathrm{O}_{2}$ fluxes were significantly larger than fluxes at a similar irradiance in the afternoon. There was no difference in mean flow velocity between morning and afternoon that could explain this pattern (October: $\mathrm{p}=0.834$, August: $\mathrm{p}=0.330$ ). During February and June, mean flow between morning and afternoon was significantly different at $\alpha=0.1(p=0.043$, 0.053, respectively), and this prevented a similar analysis.

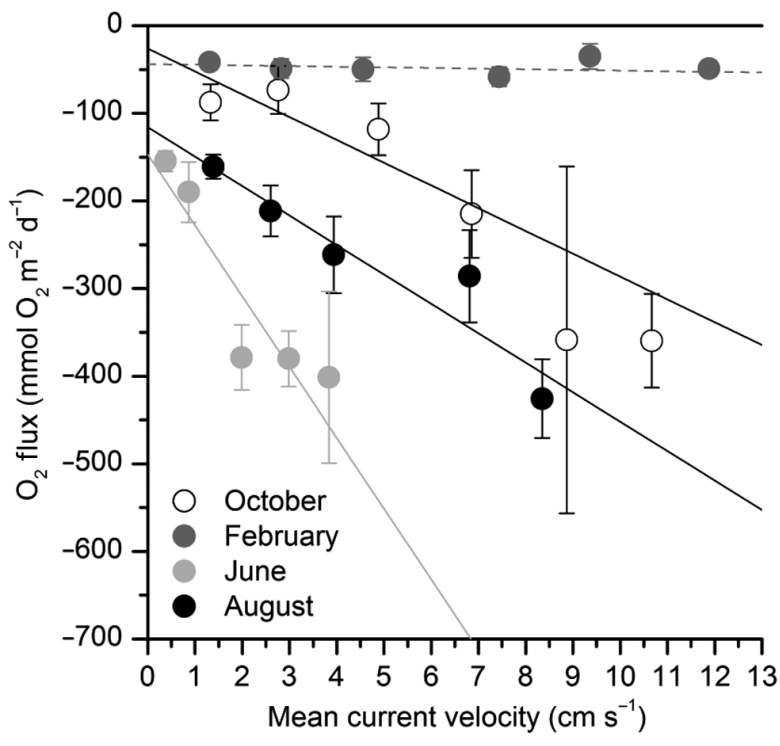

Fig. 5. Nighttime $\mathrm{O}_{2}$ flux as a function of mean velocity for October, February, June, and August. Data were binned to illustrate relationships, and significant trends were found in October, June, and August. Error bars are standard error

Both average daily (Fig. 7) and seasonal (Fig. 8A) ecosystem $\mathrm{R}$ and GPP were highly variable but always maintained a close to 1:1 relationship (Fig. 7). This indicates that the underlying $\mathrm{O}_{2}$ production and consumption processes were tightly coupled on both daily (Fig. 7) and seasonal timescales (Fig. 8A).

Rates of seasonal R and GPP were strongly correlated to seagrass shoot density (Fig. 8B, $\mathrm{r}^{2}=0.96, \mathrm{p}=$ 0.004 and $\mathrm{r}^{2}=0.83, \mathrm{p}=0.031$, respectively). The highest shoot densities were observed during June and the lowest during February (Fig. 8B). Seasonal NEM was also variable (Fig. 8A), and showed that the metabolic state of the seagrass meadow varied between autotrophy and heterotrophy during the year.

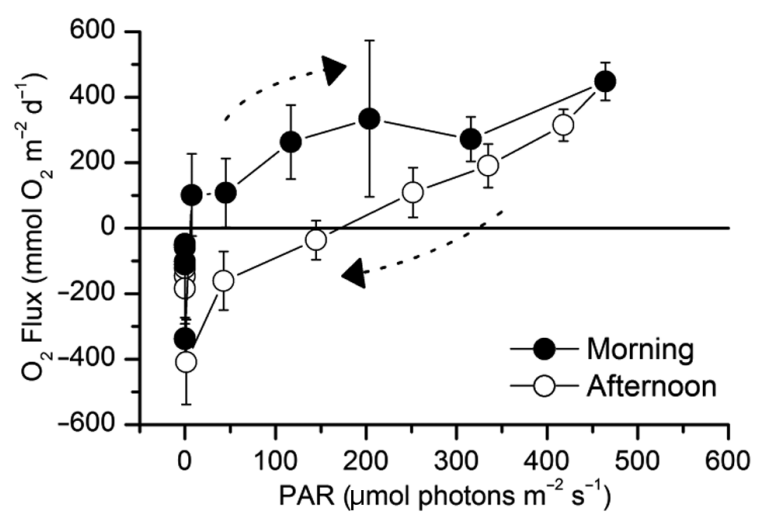

Fig. 6. Oxygen flux binned by hour of day as a function of photosynthetically active radiation (PAR) for October. Arrows symbolize the direction of the hysteresis. Error bars are standard error. Positive fluxes represent a release 


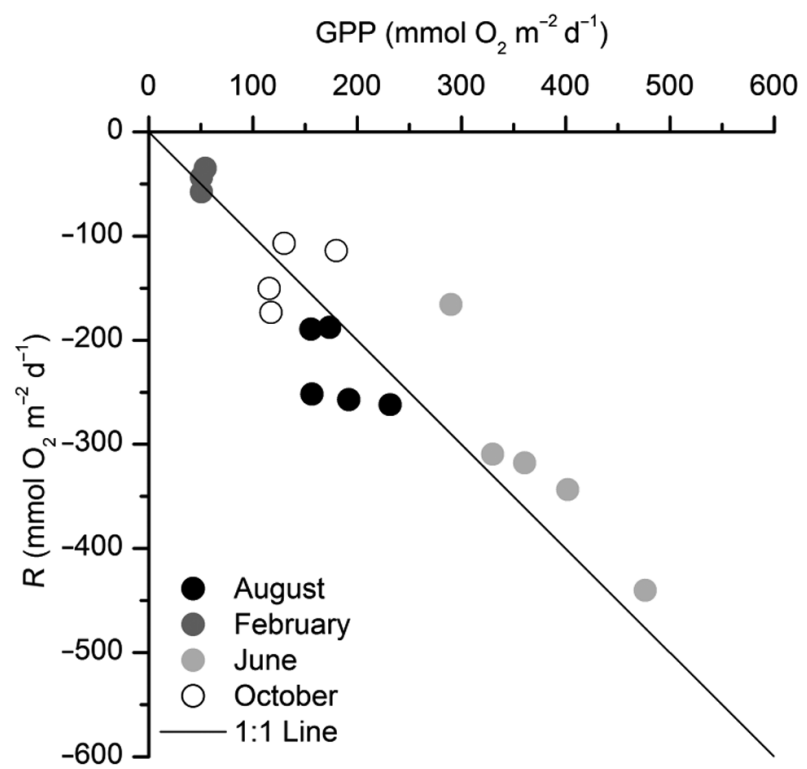

Fig. 7. Daily ecosystem gross primary production (GPP) vs. community respiration $(\mathrm{R})$ for all sampling dates

In August 2011, October 2011, February 2012, and June 2012, average NEM ( \pm SE) was $-47.6 \pm 14.5$, $-0.31 \pm 27.7,6.4 \pm 7.6$, and $55.5 \pm 15.4 \mathrm{mmol} \mathrm{O}_{2} \mathrm{~m}^{-2}$ $\mathrm{d}^{-1}$, respectively ( $\mathrm{n}=4,3,5$, and 5). Seasonal NEM was not significantly different from 0 in October and February ( $p=0.991, p=0.488$, respectively), was significantly greater than 0 in June $(p=0.037)$, and was significantly less than 0 in August $(p=0.030)$.

\section{DISCUSSION}

This study includes the most detailed data set to date on $\mathrm{O}_{2}$ fluxes and ecosystem metabolism for a seagrass meadow measured with the eddy correlation technique. These data allow us to quantify seagrass ecosystem metabolism, its drivers, and its seasonal variation under naturally varying field conditions in a way that has not been possible using other methods (Fig. 3). For example, at Hour 38 in Fig. 3, a severe storm event occurred that drastically reduced available light and increased current velocities. The storm conditions resulted in a very large drop of the net $\mathrm{O}_{2}$ flux from an hourly average of $\sim 700 \mathrm{mmol} \mathrm{O}_{2} \mathrm{~m}^{-2} \mathrm{~d}^{-1}$ to nearly 0 , a unique event that alternative approaches likely would not capture. Eddy correlation flux measurements are assumed to represent metabolism of the system as a whole because the footprint for the technique is typically on the order of $100 \mathrm{~m}^{2}$ at a measuring height such as that used in this study $(31 \mathrm{~cm})$ and incorporates spatial

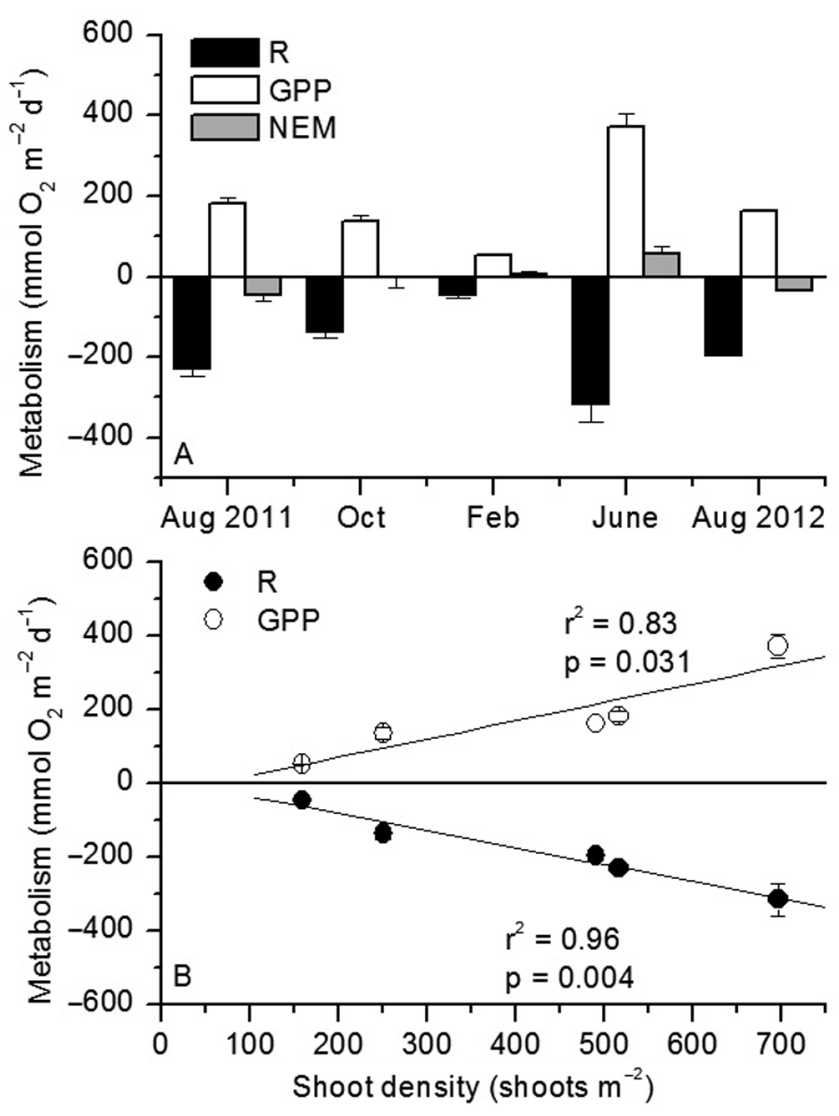

Fig. 8. (A) Seasonal average respiration (R), gross primary production (GPP), and net ecosystem metabolism (NEM) during all sampling seasons ( $\mathrm{n}=5,4,3,5,1$ for August 2011, October, February, June, and August 2012, respectively). (B) Seasonal GPP and R vs. Zostera marina shoot density. Error bars are standard error

heterogeneity that is typical of these systems (Berg et al. 2007, Rheuban \& Berg 2013). The good agreement between the cumulative fluxes from the side-by-side deployments of the 2 eddy correlation instruments (Fig. 2) indicates that we can use our measured $\mathrm{O}_{2}$ fluxes and metabolic rates as representative of the Zostera marina meadow.

\section{Short timescale: minute to hourly}

Light was the main driver of production (Figs. 3 \& 4 ), with some variation likely due to current flow (Fig. 5) and the hysteresis effect (Fig. 6). There was no significant relationship between current flow and daytime production (data not shown) when both $\mathrm{O}_{2}$ producing and consuming processes were occurring simultaneously during the day. Increased current velocity can stimulate both production (e.g. Mass et al. 2010, Hume et al. 2011) and respiration (e.g. 
Hume et al. 2011, Berg et al. 2013, Long et al. 2013) simultaneously. If stimulation of both processes was similar, the individual effects would not be able to be seen in the net $\mathrm{O}_{2}$ flux. However, flow stimulation of respiration was clearly evident in the nighttime fluxes during October, June, and August (Fig. 5), a process that has been shown before for seagrass meadows (Hume et al. 2011) and other shallow coastal systems (Precht \& Huettel 2003, Berg et al. 2013, Long et al. 2013). Higher flow can increase $\mathrm{O}_{2}$ metabolism in $Z$. marina meadows through several mechanisms. For example, increased flow reduces the leaf boundary layers and allows for faster rates of gas exchange and nutrient uptake (Binzer et al. 2005, Cornelisen \& Thomas 2006). Also, elevated turbulent mixing from increased current flow that penetrates into the canopy (Hansen \& Reidenbach 2013) can increase canopy and sediment oxygenation through flushing, by providing more $\mathrm{O}_{2}$ for respiration. The lack of flow stimulation of respiration observed during winter (Fig. 5) may be due to the combination of low biomass and reduced respiration rates at the low temperatures (Wetzel \& Penhale 1983, Moore et al. 1997, Moore 2004).

The hysteresis that was observed during October and August with respect to light, where the $\mathrm{O}_{2}$ flux during the morning was larger than the afternoon at a similar irradiance, suggests a coupling between production and respiration on an hourly timescale (Fig. 6). During October, the lower rates of net production observed in the afternoon were likely caused by a stimulation of heterotrophic respiration through the release and consumption of labile dissolved organic exudates (Penhale \& Smith 1977, Wetzel \& Penhale 1979, Glud 2008). Net production decreased by nearly $300 \mathrm{mmol} \mathrm{O}_{2} \mathrm{~m}^{-2} \mathrm{~d}^{-1}$, or approximately $90 \%$ of the maximum, at similar light values from morning to afternoon (Fig. 6). There were no differences in either current velocity or temperature that could explain this hysteresis. Geertz-Hansen et al. (2011) found a similar hysteresis in a Mediterranean lagoon and attributed it to an 8 to $10^{\circ} \mathrm{C}$ temperature change over the course of the day. In our study, temperature only differed by $1.5^{\circ} \mathrm{C}$, from 16.3 to $17.8^{\circ} \mathrm{C}$. These temperatures were well below the optimal temperature for Z. marina $\left(<28^{\circ} \mathrm{C}\right.$, Staehr \& Borum 2011), and the small difference would not increase $R$ relative to photosynthesis as much as observed. During August when temperatures were above $28^{\circ} \mathrm{C}$ $\left(28.4\right.$ to $\left.31.9^{\circ} \mathrm{C}\right)$, temperature stress rather than dissolved organic carbon stimulation of R may explain the observed hysteresis. At these high temperatures, Z. marina $\mathrm{R}$ would increase proportionately more than production, resulting in lower net production, and if sustained for a long enough period, reduced survival (Moore \& Jarvis 2008, Staehr \& Borum 2011, Moore et al. 2012).

It is possible that the hysteresis could also be caused by a decrease in photosynthesis due to photoinhibition, an increase in photooxidation (Mehler reaction, Miyake \& Asada 2003), photorespiration (Beer 1989, Frost-Christensen \& Sand-Jensen 1992, Beer et al. 1998), or nutrient limitation. However, photoinhibition and the Mehler reaction are more likely to occur at high irradiance levels (Touchette \& Burkholder 2000, Larkum et al. 2007), and we observed the largest decrease in net production during the late afternoon when irradiance was relatively low. There is little evidence of high rates of photorespiration in seagrasses due to efficient uptake and internal carbon concentration (Beer 1989, FrostChristensen \& Sand-Jensen 1992, Touchette \& Burkholder 2000). However, a recent lab study by Buapet et al. (2013) showed a reduction in seagrass gross photosynthesis with an increase in $\mathrm{O}_{2}$ concentration which they attributed to photorespiration. They found that photosynthesis could be reduced by up to $40 \%$, which may explain some of the hysteresis we observed. However, in situ conditions such as natural flow fields and turbulence may reduce photorespiration by allowing for more efficient release of $\mathrm{O}_{2}$ from seagrass leaves (Mass et al. 2010). While we do not have the data to rule out the possibility of nutrient limitation developing during the day, we think this is unlikely due to the high levels of nitrogen fixation and evidence that water column turbidity limits seagrass areal distribution rather than nutrient availability (Cole \& McGlathery 2012, McGlathery et al. 2012).

Estimates of ecosystem $\mathrm{R}$ during the day can be very difficult to obtain from $\mathrm{O}_{2}$ flux measurements (Glud 2008 and references therein), and most estimates of ecosystem $\mathrm{R}$ assume that daytime $\mathrm{R}$ is equal to nighttime R (Cole et al. 2000, Glud 2008 and references therein, Hume et al. 2011). However, from the hysteresis observed in our data, we may be able to produce a more refined estimate of daytime R. During October, if the same photosynthesis-irradiance relationship is assumed for the entire day, GPP will remain consistent from morning to afternoon at the same light levels. This means that $\mathrm{R}$ during the day in our study may be up to 2.5 -fold larger than from assuming a constant nighttime R over the $24 \mathrm{~h}$ period (Fig. 6). This substantial difference between estimated daytime and nighttime $\mathrm{R}$ is supported by studies that have separated $\mathrm{R}$ from production in marine sediments and found that daytime $\mathrm{R}$ may be up to 
4-fold higher than nighttime R (Glud 2008). We note that this underestimation of $\mathrm{R}$ would result in a similar underestimation of GPP.

\section{Daily timescale}

Daily ecosystem metabolism showed tight 1:1 coupling between GPP and R over the seasons (Fig. 7), similar to some earlier studies (Duarte et al. 2010, Hume et al. 2011). This coupling represents dayto-day variability in light and flow conditions (e.g. Fig. 5) and season-to-season variability in temperature. Increases in GPP lead to larger plant R of fixed carbon during the day and/or exudation of excess labile DOC into sediments or from leaves (Penhale \& Smith 1977, Wetzel \& Penhale 1979) that stimulates heterotrophic R. Increased R of labile DOC during the night can cause a release in nutrients which may then stimulate GPP, resulting in 2 positive feedbacks between GPP and R on a daily timescale.

\section{Long timescales: monthly to seasonal}

The observed seasonal changes in flow stimulation of nighttime $\mathrm{O}_{2}$ flux (Fig. 5) are likely linked to temperature differences, variations in shoot density that affects flow in the canopy (Hansen \& Reidenbach 2013), and areal biomass. This can be seen in the $\sim 10$-fold larger fluxes measured in summer than in winter (Fig. 5) when there was a $\sim 20^{\circ} \mathrm{C}$ difference in temperature and a $\sim 500$ shoots $\mathrm{m}^{-2}$ difference in density between seasons (Rheuban et al. in press). Between June and August, the magnitude of fluxes observed was similar, and temperature ranged between 28 and $32^{\circ} \mathrm{C}$ during both periods. However, there was a large difference in the slope of the regressions between respiration and flow during these 2 seasons (Fig. 5), and this was likely the result of the difference in $Z$. marina shoot density (Fig. 8B). Early summer is peak growth season for $Z$. marina in the Mid-Atlantic (Orth \& Moore 1986, Moore 2004, Carr et al. 2010), and the highest shoot densities were observed during this season (Rheuban et al. in press). Higher shoot densities cause more drag and dissipation of turbulence (Fonseca \& Fisher 1986, Hansen \& Reidenbach 2012, 2013), which results in close-to stagnant water within the canopy, and thus enhanced boundary layer thickness. Under these conditions, even small increases in flow may have large stimulating effects on rates of gas exchange (Binzer et al. 2005, Mass et al. 2010).
At night, seagrasses translocate $\mathrm{O}_{2}$ from the water column to the sediments through their leaf tissues to support root and rhizome $\mathrm{R}$ and also release $\mathrm{O}_{2}$ into the sediments (Binzer et al. 2005, Sand-Jensen et al. 2005). Binzer et al. (2005) found a logarithmic increase in the partial pressure of $\mathrm{O}_{2}$ in seagrass tissue with flow that they attributed to increasing passive $\mathrm{O}_{2}$ uptake from reduction in the diffusive boundary layer. This logarithmic relationship suggests that small increases in flow at low velocities may be relatively more significant to $\mathrm{O}_{2}$ uptake by seagrasses than increases at high velocities, which is supported by our findings (Fig. 5).

Differences in the magnitude of the paired GPP and $\mathrm{R}$ values (Fig. 7) reflect variations in both temperature and shoot density throughout the year (Fig. 8). Because temperature stimulates both GPP and R (Moore et al. 1997, Moore 2004, Staehr \& Borum 2011), paired GPP and R values from warmer seasons would tend to fall further down the 1:1 line (Fig. 7, June and August). However, studies have shown that temperature has a disproportionate stimulation of $\mathrm{R}$ compared to GPP (Marsh et al. 1986), which may partially explain why our data fall below the 1:1 line in August when temperatures exceeded the threshold for Z. marina growth (Staehr \& Borum 2011), while the June data are above the 1:1 line (Fig. 7). Shoot density also plays a role in the location of GPP and R on this line, as seasonal averaged GPP and R were strongly correlated to shoot density (Fig. 8B). The smaller GPP and R in August relative to June is likely the result of lower shoot densities in August due to mid-summer heat stress.

Rates of R, GPP, and NEM were highly variable depending on sampling season; however, the fluxes from our study fall well within the seasonal average variability reported in the literature (Table 2; Duarte et al. 2010). The average NEM switched from a net balance during October and February, to net autotrophic during June and to net heterotrophic during August (Fig. 8A). These results highlight the important finding that the metabolic status of a seagrass meadow cannot be determined from a single sampling season (Murray \& Wetzel 1987, Ziegler \& Benner 1998), but must be integrated over all seasons.

\section{Implications}

This study of $\mathrm{O}_{2}$ fluxes, ecosystem metabolism, and their drivers in seagrass meadows illustrates the need for seasonal measurements in order to evaluate trophic status. Using the eddy correlation technique, 


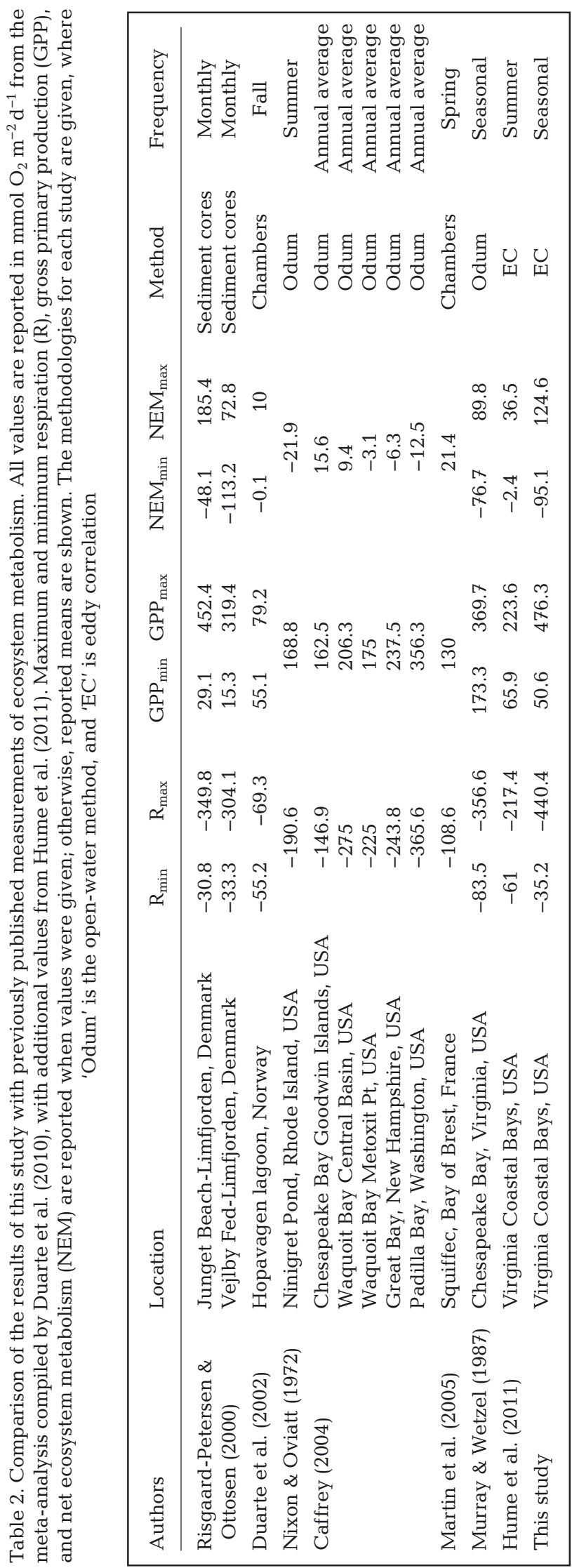

we can resolve $\mathrm{O}_{2}$ fluxes down to a 15 min timescale with measurements that characterize the seagrass ecosystem as a whole. These results can be integrated to represent metabolism on daily, seasonal, and annual timescales. The multiple timescales identified here are all important to consider when evaluating seagrass ecosystem response to environmental drivers. For example, it may be more appropriate to consider $\mathrm{O}_{2}$ fluxes on hourly or daily timescales when evaluating transient pulsed inputs of nutrients, sediment, or organic matter. Temperature or stormrelated effects on metabolism may be more appropriate to consider on daily to seasonal timescales. Seagrass meadows are important to regional and global carbon cycling, and our results document the dynamic nature of $\mathrm{O}_{2}$ fluxes that, when integrated over time, translate into highly variable rates of ecosystem-scale metabolism over daily to seasonal timescales. This variation must be incorporated into accurate estimates of trophic status of seagrass meadows.

Acknowledgements. We thank 3 anonymous reviewers for improving this manuscript substantially. Support for this study was provided by the University of Virginia and the National Science Foundation through grants from the Chemical Oceanography program (OCE-0536431 and OCE1061364) and the Division of Environmental Biology to the Virginia Coast Reserve Long Term Ecological Research Program (DEB-0621014 and DEB-1237733).

\section{LITERATURE CITED}

Barrón C, Marba N, Terrados J, Kennedy H, Duarte CM (2004) Community metabolism and carbon budget along a gradient of seagrass (Cymodocea nodosa) colonization. Limnol Oceanogr 49:1642-1651

Barrón C, Duarte CM, Frankignoulle M, Borges AV (2006) Organic carbon metabolism and carbonate dynamics in a Mediterranean seagrass (Posidonia oceanica) meadow. Estuar Coast 29:417-426

Beer S (1989) Photosynthesis and photorespiration of marine angiosperms. Aquat Bot 34:153-166

Beer S, Vilenkin B, Weil A, Veste M, Susel L, Eshel A (1998) Measuring photosynthetic rates in seagrasses by pulse amplitude modulated (PAM) fluorometry. Mar Ecol Prog Ser 174:293-300

> Berg P, Huettel M (2008) Monitoring the seafloor using the noninvasive eddy correlation technique: integrated benthic exchange dynamics. Oceanography 21:164-167

> Berg P, Røy H, Janssen F, Meyer V, Jørgensen BB, Huettel M, de Beer D (2003) Oxygen uptake by aquatic sediments measured with a novel non-invasive eddy-correlation technique. Mar Ecol Prog Ser 261:75-83

> Berg P, Røy H, Wiberg PL (2007) Eddy correlation flux measurements: the sediment surface area that contributes to the flux. Limnol Oceanogr 52:1672-1684

Berg P, Long MH, Huettel M, Rheuban JE and others (2013) Eddy correlation measurements of oxygen fluxes in permeable sediments exposed to varying current flow and 
light. Limnol Oceanogr 58:1329-1343

Binzer T, Borum J, Pedersen O (2005) Flow velocity affects internal oxygen conditions in the seagrass Cymodocea nodosa. Aquat Bot 83:239-247

> Buapet P, Rasmusson LM, Gullström M, Björk M (2013) Photorespiration and carbon limitation determine productivity in temperate seagrasses. PLoS ONE 8:e83804

> Caffrey JM (2004) Factors controlling net ecosystem metabolism in US estuaries. Estuaries 27:90-101

> Canfield DE, Jørgensen BB, Fossing H, Glud R and others (1993) Pathways of organic carbon oxidation in three continental margin sediments. Mar Geol 113:27-40

Carr J, D'Odorico P, McGlathery K, Wiberg P (2010) Stability and bistability of seagrass ecosystems in shallow coastal lagoons: role of feedbacks with sediment resuspension and light attenuation. J Geophys Res 115: G03011, doi:10.1029/2009JG001103

> Cole JJ, Pace ML, Carpenter SR, Kitchell JF (2000) Persistence of net heterotrophy in lakes during nutrient addition and food web manipulations. Limnol Oceanogr 45: 1718-1730

> Cole LW, McGlathery KJ (2012) Nitrogen fixation in restored eelgrass meadows. Mar Ecol Prog Ser 448:235-246

Cornelisen CD, Thomas FIM (2006) Water flow enhances ammonium and nitrate uptake in a seagrass community. Mar Ecol Prog Ser 312:1-13

> Duarte CM, Martínez R, Barrón C (2002) Biomass, production, and rhizome growth near the northern limit of seagrass (Zostera marina) distribution. Aquat Bot 72:183-189

> Duarte CM, Marba N, Gacia E, Fourqurean JW, Beggins J, Barrón C, Apostolaki ET (2010) Seagrass community metabolism: assessing the carbon sink capacity of seagrass meadows. Global Biogeochem Cycles 24:GB4302, doi:10.1029/2010GB003793

Duarte CM, Kennedy H, Marba N, Hendriks I (2011) Assessing the capacity of seagrass meadows for carbon burial: current limitations and future strategies. Ocean Coast Manag 10:1-11

Eyre BD, Maher D, Oakes JM, Erler DV, Glasby TM (2011) Differences in benthic metabolism, nutrient fluxes, and denitrification in Caulerpa taxifolia communities compared to uninvaded bare sediment and seagrass (Zostera capricorni) habitats. Limnol Oceanogr 56:1737-1750

Fonseca MS, Fisher JS (1986) A comparison of canopy friction and sediment movement between four species of seagrass with reference to their ecology and restoration. Mar Ecol Prog Ser 29:15-22

Fourqurean JW, Duarte CM, Kennedy H, Marbà N and others (2012) Seagrass ecosystems as a globally significant carbon stock. Nat Geosci 5:505-509

- Frost-Christensen H, Sand-Jensen K (1992) The quantum efficiency of photosynthesis in macroalgae and submerged angiosperms. Oecologia 91:377-384

Gacia E, Duarte CM, Middleburg J (2002) Carbon and nutrient deposition in a Mediterranean seagrass (Posidonia oceanica) meadow. Limnol Oceanogr 47:23-32

Geertz-Hansen O, Montes C, Duarte CM, Sand-Jensen K, Marbá N, Grillas P (2011) Ecosystem metabolism in a temporary Mediterranean marsh (Doñana National Park, SW Spain). Biogeosciences 8:963-971

> Glud RN (2008) Oxygen dynamics of marine sediments. Mar Biol Res 4:243-289

Glud RN, Berg P, Hume A, Batty P, Blicher ME, Lennert K, Rysgaard S (2010) Benthic $\mathrm{O}_{2}$ exchange across hardbottom substrates quantified by eddy correlation in a
sub-Arctic fjord. Mar Ecol Prog Ser 417:1-12

> Greiner JT, McGlathery KJ, Gunnell J, McKee BA (2013) Seagrass restoration enhances 'blue carbon' sequestration in coastal waters. PLoS ONE 8(8): e72469

> Hansen JCR, Reidenbach MA (2012) Wave and tidally driven flows in eelgrass beds and their effect on sediment suspension. Mar Ecol Prog Ser 448:271-287

Hansen JCR, Reidenbach MA (2013) Seasonal growth and senescence of a Zostera marina seagrass meadow alters wave-dominated flow and sediment suspension within a coastal bay. Estuar Coast 36:1099-1114

Heip CHR, Goosen NK, Herman PMJ, Kromkamp J, Middelburg JJ, Soetart K (1995) Production and consumption of biological particles in temperate tidal estuaries. Oceanogr Mar Biol Annu Rev 33:1-149

Holtappels M, Glud RN, Donis D, Hume A, Wenzhofer F, Kuypers MMM (2013) Effects of transient bottom water currents and oxygen concentrations on benthic exchange rates as assessed by eddy correlation measurements. J Geophys Res: Oceans 118:1157-1169

Hume A, Berg P, McGlathery K (2011) Dissolved oxygen fluxes and ecosystem metabolism in an eelgrass (Zostera marina) meadow measured with the eddy correlation technique. Limnol Oceanogr 56:86-96

Kennedy H, Beggins J, Duarte CM, Fourqurean JW, Holmer M, Marba N, Middleburg JJ (2010) Seagrass sediments as a global carbon sink: isotopic constraints. Global Biogeochem Cycles. GB4026, doi:10.1029/2010GB003848

Larkum AWD, Drew EA, Ralph PJ (2007) Photosynthesis and metabolism in seagrasses at the cellular level. In: Larkum AWD, Orth RJ, Duarte CM (eds) Seagrasses: biology, ecology, and conservation. Springer, Dordrecht, p 323-345

Lee X, Massman W, Law B (2004) Handbook of micrometeorology: a guide for surface flux measurement and analysis. Kluwer Academic Publishers, Dordrecht

Long MH, Rheuban JE, Berg P, Zieman JC (2012) A comparison and correction of light intensity loggers to photosynthetically active radiation sensors. Limnol Oceanogr Methods 10:416-424

Long MH, Berg P, de Beer D, Zieman JC (2013) In situ coral reef oxygen metabolism: an eddy correlation study. PLoS ONE 8(3): e58581

> Lorke A, McGinnis DF, Maeck A (2013) Eddy-correlation measurements of benthic fluxes under complex flow conditions: effects of coordinate transformations and averaging time scales. Limnol Oceanogr Methods 11:425-437

> Lorrai C, McGinnis DF, Brand A, Wüest A (2010) Application of oxygen eddy correlation in aquatic systems. J Atmos Ocean Technol 27:1533-1546

- Marsh JA Jr, Dennison WC, Alberte RS (1986) Effects of temperature on photosynthesis and respiration in eelgrass (Zostera marina L.). J Exp Mar Biol Ecol 101: 257-267

Martin S, Clavier J, Guarini J, Chauvaud L and others (2005) Comparison of Zostera marina and maerl community metabolism. Aquat Bot 83:161-174

Masini RJ, Manning CR (1997) The photosynthetic responses to irradiance and temperature of four meadowforming seagrasses. Aquat Bot 58:21-36

> Mass T, Genin A, Shavit U, Grinstein M, Tchernov D (2010) Flow enhances photosynthesis in marine benthic autotrophs by increasing the efflux of oxygen from the organism to the water. Proc Natl Acad Sci USA 107:2527-2531

Massey FJ (1951) The kolmogorov-Smirnov test for goodness of fit. J Am Stat Assoc 46(253):68-78 
McGinnis DF, Cherednichenko S, Sommer S, Berg P and others (2011) Simple, robust eddy correlation amplifier for aquatic dissolved oxygen and hydrogen sulfide flux measurements. Limnol Oceanogr Methods 9:340-347

McGlathery KJ, Sundbäck K, Anderson IC (2007) Eutrophication in shallow coastal bays and lagoons: the role of plants in the coastal filter. Mar Ecol Prog Ser 348:1-18

McGlathery KJ, Reynolds LK, Cole LW, Orth RJ, Marion SR, Schwarzschild A (2012) Recovery trajectories during state change from bare sediment to eelgrass dominance. Mar Ecol Prog Ser 448:209-221

Mcleod E, Chmura GL, Bouillon S, Salm R and others (2011) A blueprint for blue carbon: toward an improved understanding of the role of vegetated coastal habitats in sequestering $\mathrm{CO}_{2}$. Front Ecol Environ 9:552-560

Miyake C, Asada K (2003) The water-water cycle as an alternative electron flux around PSI in algae. In: Larkum AWD, Douglas S, Raven JA (eds) Photosynthesis in algae. Kluwer Publ., Dordrecht, p 183-204

> Moore KA (2004) Influence of seagrasses on water quality in shallow regions of the lower Chesapeake Bay. J Coast Res 45(Spec Issue):162-178

> Moore KA, Jarvis JC (2008) Environmental factors affecting recent summertime eelgrass diebacks in the lower Chesapeake Bay: implications for long term persistence. J Coast Res 55(Spec Issue):135-147

> Moore KA, Wetzel RL, Orth RJ (1997) Seasonal pulses of turbidity and their relations to eelgrass (Zostera marina L.) survival in an estuary. J Exp Mar Biol Ecol 215:115-134

Moore KA, Shields EC, Parrish DB, Orth RJ (2012) Eelgrass survival in two contrasting systems: role of turbidity and summer water temperatures. Mar Ecol Prog Ser 448: $247-258$

Murray L, Wetzel RL (1987) Oxygen production and consumption associated with the major autotrophic components in two temperate seagrass communities. Mar Ecol Prog Ser 38:231-239

$>$ Nixon SW, Oviatt CA (1972) Preliminary measurements of midsummer metabolism in beds of eelgrass, Zostera marina. Ecology 53:150-153

$>$ Odum HT (1956) Primary production in flowing waters. Limnol Oceanogr 1:102-117

> Orth RJ, Moore K (1986) Seasonal and year-to-year variations in the growth of Zostera marina L. (eelgrass) in the lower Chesapeake Bay. Aquat Bot 24:335-341

> Orth RJ, Luckenbach ML, Marion SR, Moore KA, Wilcox DJ (2006) Seagrass recovery in the Delmarva Coastal Bays, USA. Aquat Bot 84:26-36

Orth RJ, Marion SR, Moore KA, Wilcox DJ (2010) Eelgrass (Zostera marina L.) in the Chesapeake Bay region of mid-Atlantic coast of the USA: challenges in conservation and restoration. Estuar Coast 33:139-150

> Orth RJ, Moore KA, Marion SR, Wilcox DJ, Parrish DB

Editorial responsibility: William Kemp,

Cambridge, Maryland, USA
(2012) Seed addition facilitates eelgrass recovery in a coastal bay system. Mar Ecol Prog Ser 448:177-195

Penhale PA, Smith WO Jr (1977) Excretion of dissolved organic carbon by eelgrass (Zostera marina) and its epiphytes. Limnol Oceanogr 22:400-407

Precht E, Huettel M (2003) Advective pore-water exchange driven by surface gravity waves and its ecological implications. Limnol Oceanogr 48:1674-1684

Raymond P, Cole J (2001) Gas exchange in rivers and estuaries: choosing a gas transfer velocity. Estuaries 24: 312-317

Reimers CE, Ozkan-Haller HT, Berg P, Devol A, McCannGrosvenor K, Sanders RD (2012) Benthic oxygen consumption rates during hypoxic conditions on the Oregon continental shelf: evaluation of the eddy correlation method. J Geophys Res 117:1-18

Reynolds LK, McGlathery KJ, Waycott M (2012) Genetic diversity enhances restoration success by augmenting ecosystem services. PLoS ONE 7(6): e38397

Rheuban JE, Berg P (2013) The effects of spatial and temporal variability at the sediment surface on aquatic eddy correlation flux measurements. Limnol Oceanogr Methods 11:351-359

Rheuban JE, Berg P, McGlathery KJ (in press) Ecosystem metabolism along a colonization gradient of eelgrass (Zostera marina) measured by eddy correlation. Limnol Oceanogr

Risgaard-Petersen N, Ottosen LDM (2000) Nitrogen cycling in two temperate Zostera marina beds: seasonal variation. Mar Ecol Prog Ser 198:93-107

Sand-Jensen K, Pedersen O, Binzer T, Borum J (2005) Contrasting oxygen dynamics in the freshwater isoetid Lobelia dortmanna and the marine seagrass Zostera marina. Ann Bot (Lond) 96:613-623

Short F, Carruthers T, Dennison W, Waycott M (2007) Global seagrass distribution and diversity: a bioregional model. J Exp Mar Biol Ecol 350:3-20

Staehr PA, Borum J (2011) Seasonal acclimation in metabolism reduces light requirements of eelgrass (Zostera marina). J Exp Mar Biol Ecol 407:139-146

Touchette BW, Burkholder JM (2000) Overview of the physiological ecology of carbon metabolism in seagrasses. J Exp Mar Biol Ecol 250:169-205

Wetzel RG, Penhale PA (1979) Transport of carbon and excretion of dissolved organic carbon by leaves and roots/ rhizomes in seagrasses and their epiphytes. Aquat Bot 6: 149-158

Wetzel RL, Penhale PA (1983) Production ecology of seagrass communities in the lower Chesapeake Bay. Mar Technol Soc J 17:22-31

> Ziegler S, Benner R (1998) Ecosystem metabolism in a subtropical, seagrass-dominated lagoon. Mar Ecol Prog Ser $173: 1-12$

Submitted: July 24, 2013; Accepted: May 5, 2014

Proofs received from author(s): June 5, 2014 